\title{
Simultaneous Detection of Cd (II), Pb (II), Cu (II), and Hg (II) Ions in Dye Waste Water Using a Boron Doped Diamond Electrode with DPASV
}

\author{
Jang-Hee Yoon, JeeEun Yang, ${ }^{\dagger}$ JongPhil Kim, JongSeong Bae, Yoon-Bo Shim, ${ }^{\dagger}$ and Mi-Sook Won* \\ Busan Center, Korea Basic Science Institute, Busan 609-735, Korea. *E-mail: mswon@kbsi.re.kr \\ ${ }^{\dagger}$ Department of Chemistry, Pusan National University, Busan 609-735, Korea \\ Received October 17, 2009, Accepted November 28, 2009
}

\begin{abstract}
The simultaneous detection of $\mathrm{Cd}$ (II), $\mathrm{Pb}$ (II), $\mathrm{Cu}$ (II), and $\mathrm{Hg}$ (II) ions in aqueous medium using a BDD electrode with DPASV is described. XPS was used to characterize the chemical states of trace metal ions deposited on the BDD electrode surface. Experimental parameters that affect response, such as $\mathrm{pH}$, deposition time, deposition potential, and pulse amplitude were carefully optimized. The detection limits for $\mathrm{Cd}$ (II), $\mathrm{Pb}$ (II), $\mathrm{Cu}$ (II), and $\mathrm{Hg}$ (II) ions were 3.5 ppb, $2.0 \mathrm{ppb}, 0.1 \mathrm{ppb}$ and $0.7 \mathrm{ppb}$, respectively. The application of the BDD electrode on the electrochemical pretreatment for the simultaneous metal detection in the dye waste water was also investigated.
\end{abstract}

Key Words: Boron doped diamond (BDD) electrode, Differential pulse anodic stripping voltammetry (DPASV), Trace metal ions, Waste water

\section{Introduction}

Exposure to high levels of trace metal ions (e.g., $\mathrm{Cd}$ (II), $\mathrm{Pb}$ (II), $\mathrm{Cu}$ (II), and $\mathrm{Hg}$ (II)) poses a variety of health problems, because they tend to accumulate in the body, are toxic, and have a low rate of clearance. ${ }^{1,2}$ Therefore, it is critical to minimize the exposure of humans to these contaminants and this can be ensured through effective water quality monitoring.

There are several methods available for the determination of trace metals ions, which include atomic absorption spectroscopy, ${ }^{3}$ inductively coupled plasma mass spectrometry, ${ }_{5}^{4}$ highperformance liquid chromatography, ${ }^{5}$ capillary electrophoresis, ${ }^{6}$ and anodic stripping voltammetry (ASV). ${ }^{7}$ Among these methods, ASV is commonly employed because of its wide linear dynamic range, low detection limit (ppb), and multi-element analysis capability. An additional advantage of ASV over other methods is the simplicity of the instrumentation, which is relatively inexpensive and small in size, requires low levels of electrical power and is sufficiently portable to permit its use in the field. In addition, ASV has been used successfully for the determination of heavy metals in water. ${ }^{8}$ The sensitivity of differential pulse polarography is higher than other classical polarography, because of its enhanced faradaic current and decreased nonfaradaic charging current.

A hanging mercury drop electrode, ${ }^{9}$ or a mercury film-coated electrode, ${ }^{7}$ can be used for the stripping analysis of trace metals. Mercury has a large cathodic potential limit, reproducible response, and good sensitivity; however, it has the drawbacks, of its toxicity and volatility. Thus, a need exists to develop mercuryfree electrodes, which is a Nafion/crown-ether film glassy carbon electrode. ${ }^{10}$ An EDTA bonded conducting polymer modified electrode ${ }^{11}$ has also been used successfully for the stripping analysis of trace metal ions. However, this type of electrode can only be used for a few days, because of the loss of polymer and EDTA from the electrode surface to the solution during its regeneration in a $0.1 \mathrm{M} \mathrm{HNO}_{3}$ solution. $\mathrm{Ir}^{12}{ }^{12} \mathrm{Au},{ }^{13}$ and $\mathrm{Ag}^{14}$ electrodes have also been used for the stripping analysis of trace metals, but they lack sensitivity compared to a $\mathrm{Hg}$ electrode. Bismuth has been reported to show promising performance for the stripping analysis of trace metal ions, but it has a low anodic potential limit. ${ }^{15,16}$ A recent study reported that boron-doped diamond (BDD) electrodes show good electrical conductivity, low background current, wide anodic current, and non-toxicity favor and are thus promising candidates for use in the detection of a trace lead ions. ${ }^{17}$ BDD electrodes have been successfully used for the simultaneous determination of $\mathrm{Pb}$ and $\mathrm{Cu}$ in solutions using $\mathrm{ASV}^{18}$ and for the interaction of $\mathrm{Pb}$ and $\mathrm{Cd}$ by $\mathrm{ASV},{ }^{19}$ and for the determination of mixtures of $\mathrm{Zn}$ (II), $\mathrm{Cd}$ (II), $\mathrm{Pb}$ (II), and $\mathrm{Cu}$ (II) ${ }^{20}$ However, the simultaneous determination of mixtures of Cd (II), $\mathrm{Pb}$ (II), $\mathrm{Cu}$ (II), and $\mathrm{Hg}$ (II) ions with DPASV using a BDD electrode and its use in conjunction with an electrochemical pretreatment of actual waste water has not yet been reported.

In this study, we optimized the experimental conditions for the simultaneous determination of $\mathrm{Cd}$ (II), $\mathrm{Pb}$ (II), $\mathrm{Cu}$ (II), and $\mathrm{Hg}$ (II) ions with DPASV. The chemical states of the trace metal ions on the BDD electrode were characterized by XPS. Various experimental parameters that affect the sensitivity of BDD, including $\mathrm{pH}$, deposition time, deposition potential, and pulse amplitude were optimized. Interference by $\mathrm{Zn}$ (II), Co (II), Fe (II), and $\mathrm{Ni}$ (II) in the determination of $\mathrm{Cd}$ (II), $\mathrm{Pb}$ (II), $\mathrm{Cu}$ (II), and $\mathrm{Hg}$ (II) were investigated by DPASV using a BDD electrode. The response of the $\mathrm{BDD}$ electrode was compared with that for a $\mathrm{GC}$ electrode under optimized conditions and was used for the simultaneous determination of $\mathrm{Cd}$ (II), $\mathrm{Pb}$ (II), $\mathrm{Cu}$ (II), and $\mathrm{Hg}$ (II) ions in actual waste water samples.

\section{Experimental}

Reagents. Standard metal ion solutions of 1000 ppm were obtained from the Kanto chemical Co. Inc., and stepwise diluted to adequate concentrations immediately prior to use. An acetate buffer solution was prepared by adjusting a $0.2 \mathrm{M}$ solution of sodium acetate (Aldrich) to the desired $\mathrm{pH}$ by adding $0.2 \mathrm{M}$ ace- 
tic acid. A phosphate buffer solution was prepared by combining appropriate volumes of $0.1 \mathrm{M}$ disodium hydrogen phosphate (Sigma) and 0.1 M sodium dihydrogen phosphate (Aldrich). Other chemicals used in the study were of analytical reagent grade. Distilled water was obtained using a Milli-Q water purification system (18 M $\Omega . c m)$.

Apparatus. A boron doped diamond electrode (BDD), an Ag/ $\mathrm{AgCl}$ (sat'd $\mathrm{KCl}$ ), and a spiral Pt wire were used as the working, reference, and counter electrode, respectively. Electrochemical equipment consisting of a potentiostate/galvanostate (Model KST-P1, Kosentech Co. South Korea) was used in the stripping analysis. Oxygen was removed by purging solutions with $\mathrm{N}_{2}$ gas for $10 \mathrm{~min}$ prior to each measurement, and was also flowed overthe solution during the experiment. An Escalab 250 XPS spectrometer from VG Scientifics (UK) equipped with a monochromatic Al K $\alpha$ X-ray source was used to collect the XPS data at KBSI (Busan, Korea). Electrochemical degradation was accomplished using an in-house fabricated flow through electrochemical cell. The reactant solution was circulated by means of a Master Flex ${ }^{\circledR} \mathrm{L} / \mathrm{S}$ Micro pump (Cole-Parmer Instrument Company, USA) while the electrochemical degradation progressed.

Procedure. Differential pulse anodic stripping voltammetry (DPASV) was used for all experiments. The potential for deposition was usually chosen at $-1.5 \mathrm{~V} / \mathrm{Ag} / \mathrm{AgCl}$ (sat'd $\mathrm{KCl}$ ) and various deposition time times ( $1 \mathrm{~min} \sim 10 \mathrm{~min}$ ) were used. Metals were electrochemically deposited on the BDD in an acetate buffer solution containing a 100 ppb Cd (II), $\mathrm{Pb}$ (II), $\mathrm{Cu}$ (II), and $\mathrm{Hg}$ (II) ions solution for $10 \mathrm{~min}$ at a potential of $-1.5 \mathrm{~V}$. A rest time of $15 \mathrm{~s}$ was always applied after deposition, with the stirring being stopped. The potential scan was performed from -1.5 to $+1.0 \mathrm{~V} / \mathrm{Ag} / \mathrm{AgCl}$ at a scan rate of $50 \mathrm{mV} \mathrm{s}^{-1}$, a potential amplitude of $50 \mathrm{mV}$, a pulse width of $50 \mathrm{~ms}$ and a pulse period of $100 \mathrm{~ms}$, in an acetate buffer solution. After each experiment, the application of $\mathrm{a}-1.5 \mathrm{~V}$ potential for $300 \mathrm{~s}$ was sufficient to remove the deposited species from the working electrode. The BDD was cleaned by treatment with $3 \%$ nitric acid, followed by rinsing with ethanol and deionized water. The surface of the working electrode was carefully polished with an abrasive sheet. After polishing, the electrode was sonicated for $2 \mathrm{~min}$ in an ultrasonic bath to clean the surface and to remove any polishing residue.

\section{Results and Discussion}

Characterization of the trace metal deposited BDD electrode surface. Metals were electrochemically deposited on the BDD in an acetate buffer solution containing a 1 ppm Cd (II), $\mathrm{Pb}$ (II), $\mathrm{Cu}$ (II), and $\mathrm{Hg}$ (II) ions solution for $10 \mathrm{~min}$ at a potential of -1.5 $\mathrm{V}$. The XPS spectra of the metal deposited BDD electrode clearly showed all of the metal peaks, including peaks corresponding to $\mathrm{Cd} \mathrm{3d,} \mathrm{Pb} 4 \mathrm{f}, \mathrm{Cu} 2 \mathrm{p}$, and $\mathrm{Hg} 4 \mathrm{f}$, as shown in Fig. 1(a). Fig. 1(b) shows the an XPS spectrum of Cd $3 \mathrm{~d}$. The XPS peaks at $405.2 \mathrm{eV}\left(\mathrm{Cd} \mathrm{3d}_{5 / 2}\right)$ and $411.9 \mathrm{eV}\left(\mathrm{Cd} 3 \mathrm{~d}_{3 / 2}\right)$, indicate the presence of metallic $\mathrm{Cd}$ on the electrode surface, ${ }^{21} \mathrm{The} \mathrm{Pb} 4 \mathrm{f}$ spectrum exhibits the metallic character represented by $\mathrm{Pb}^{0}$ at binding energies of $137.0\left(\mathrm{~Pb} \mathrm{4f}_{7 / 2}\right)$ and $142.7 \mathrm{eV}\left(\mathrm{Pb} \mathrm{4f}_{5 / 2}\right)$, as shown in Fig. 1(c). The binding energy of $\mathrm{Cu} 2 \mathrm{p}$ is $932.7 \mathrm{eV}$ (doublet separation of $\mathrm{Cu} 2 \mathrm{p}, \Delta=19.8 \mathrm{eV}$ ), the value of which corresponds to that of $\mathrm{Cu}^{0}{ }^{21}$ as shown in Fig. 1(d). The XPS spectrum of $\mathrm{Hg} 4 \mathrm{f}$ resulted into two peaks with binding energies of $99.7\left(\mathrm{Hg} 4 \mathrm{f}_{7 / 2}\right)$, and $103.8 \mathrm{eV}\left(\mathrm{Hg} 4 \mathrm{f}_{5 / 2}\right)$ confirming that $\mathrm{Hg}$ also is present in the elemental state, as shown in Fig. 1(e). The above XPS results confirm that all of the metal ions, including $\mathrm{Cu}$ (II), $\mathrm{Pb}$ (II), $\mathrm{Cd}$ (II), and $\mathrm{Hg}$ (II), were clearly deposited onto the BDD electrode surface in the metallic state at a deposition potential of $-1.5 \mathrm{~V}$.

Electrochemical response of BDD electrodes for metal ions. The adsorption of the metal ions on the BDD electrode was carried out by immersing the BDD electrode in a $0.1 \mathrm{M} \mathrm{KNO}_{3}$ containing 100 ppb of Cd(II), $\mathrm{Pb}$ (II), Cu (II), Hg (II), Fe (II), Zn (II), $\mathrm{Ni}$ (II), and $\mathrm{Co}$ (II) for $5 \mathrm{~min}$ at a potential of $-1.5 \mathrm{~V}$ with stirring. After adsorption of the metal ions in the preconcentration solution, the BDD electrode was removed, washed with distilled water and then transferred to a cell containing a $0.1 \mathrm{M}$ $\mathrm{KNO}_{3}$ solution. DPASV for the BDD electrode was recorded from $-1.5 \mathrm{~V}$ to $+1.0 \mathrm{~V}$ at a scan rate of $50 \mathrm{mV} / \mathrm{s}$. The DPASV exhibited four peaks at $-0.70,-0.37,0.03$, and $0.30 \mathrm{~V} v s . \mathrm{Ag} /$ $\mathrm{AgCl}$, corresponding to the oxidation of the reduced $\mathrm{Cd}(0), \mathrm{Pb}$ (0), $\mathrm{Cu}(0)$, and $\mathrm{Hg}(0)$ to $\mathrm{Cd}$ (II), $\mathrm{Pb}$ (II), $\mathrm{Cu}$ (II), and $\mathrm{Hg}$ (II), respectively (Fig. 2). DPASV for the BDD electrode did not show a response for $\mathrm{Fe}$ (II), $\mathrm{Zn}$ (II), $\mathrm{Ni}$ (II), and $\mathrm{Co}$ (II) ions. This indicates that $\mathrm{Fe}$ (II), $\mathrm{Zn}$ (II), Ni (II), and Co (II) ions, when present in a sample solution, would not be expected to interfere with the simultaneous determination of $\mathrm{Cd}$ (II), $\mathrm{Pb}$ (II), $\mathrm{Cu}$ (II), and $\mathrm{Hg}$ (II).

\section{Optimization.}

Deposition potential: All experiments were carried out using $100 \mathrm{ppb}$ of each metal and the acetate buffer was selected to provide a stable $\mathrm{pH}$ value ( $\mathrm{pH}$ 6.0). To obtain an appreciable signal for the anodic stripping peaks, it was rapidly recognized that a cathodic deposition potential that is much higher than the peak value of each metal was necessary. Fig. 3(a) shows a plot of the peak amplitude as a function of deposition potential. These results clearly indicate that a potential lower than $-1.5 \mathrm{~V}$ is necessary in the absence of mercury, while in the presence of mercury, a-1.0 V appears to be more suitable. A BDD electrode may operate down to very lower cathodic potential, because the window potential of the BDD electrode can be even lower than that of hydrogen evolution. Therefore, $-1.5 \mathrm{~V}$ was chosen as the optimum deposition potential.

Deposition time: In anodic stripping, an increase in deposition time usually leads to a proportional increase in the peak current. Fig. 3(b) shows the current efficiency as a function of deposition time, when the deposition time is varied from 1 to $10 \mathrm{~min}$. The peak currents of $\mathrm{Pb}$ (II), $\mathrm{Cu}$ (II), and $\mathrm{Hg}$ (II) increased from 1 to $10 \mathrm{~min}$. This indicates that the uptake of metal ions on the electrode surface is enhanced at longer deposition times. However, the peak current for $\mathrm{Cd}$ (II) decreased over $7 \mathrm{~min}$ and we observed cross-interference effects due to interactions between $\mathrm{Pb}$ and $\mathrm{Cd}$. Therefore, for the given condition, $5 \mathrm{~min}$ was used as the optimum deposition time.

The effects of solution pH and buffer: Fig. 4(a) shows the effect of the $\mathrm{pH}$ of the solution on peak currents after immersing the BDD electrode in $0.1 \mathrm{M}$ phosphate buffer solutions in the $\mathrm{pH}$ range of 5.0 - 7.0. In this case, the deposition was carried out using a solution containing $100 \mathrm{ppb}$ each of $\mathrm{Cd}$ (II), $\mathrm{Pb}$ (II), $\mathrm{Cu}$ 
(a)

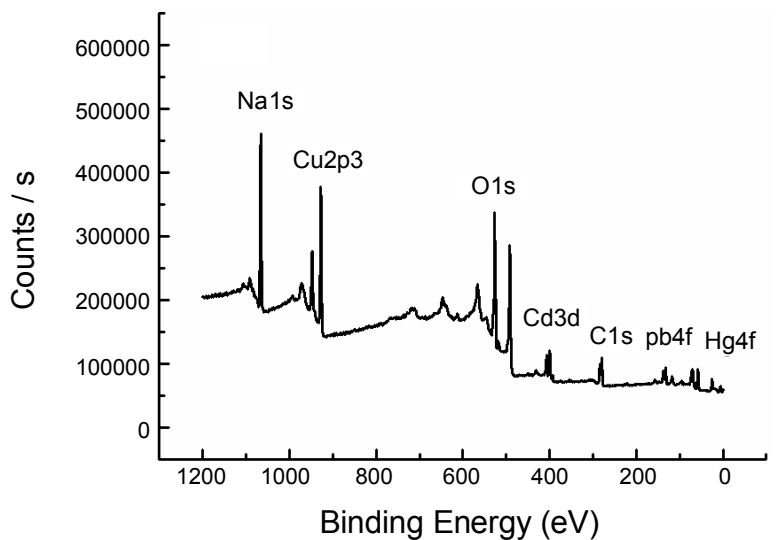

(c)

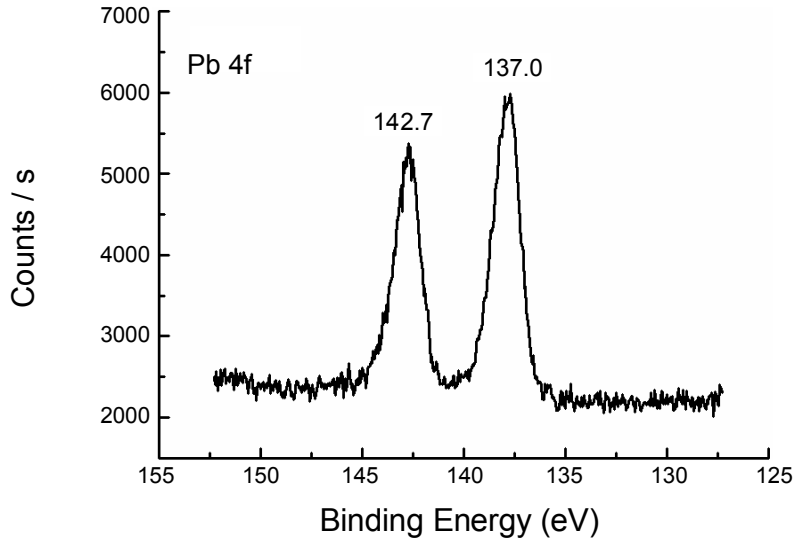

(b)

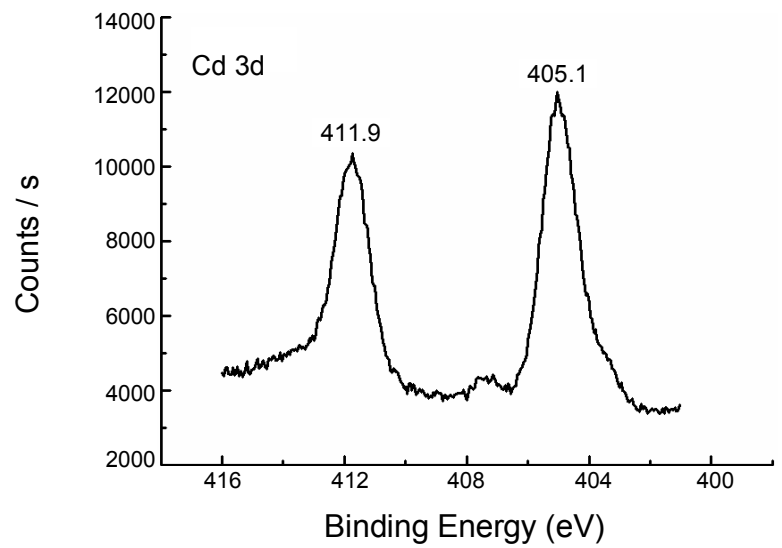

(d)

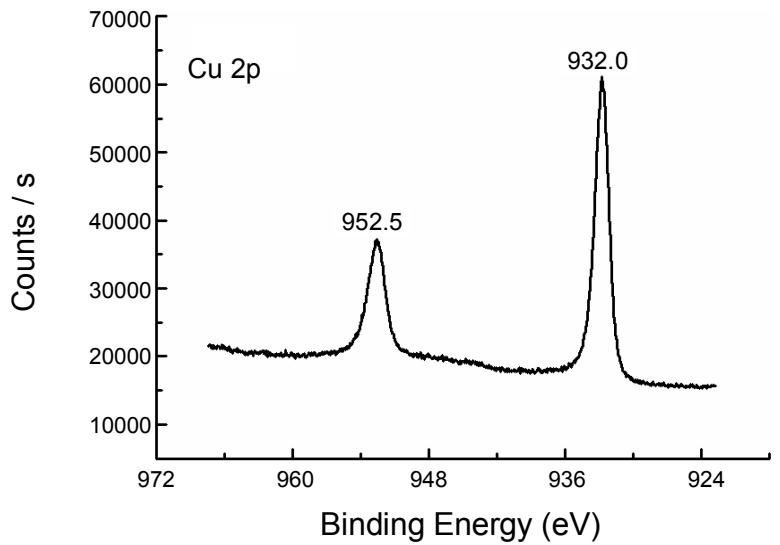

(e)

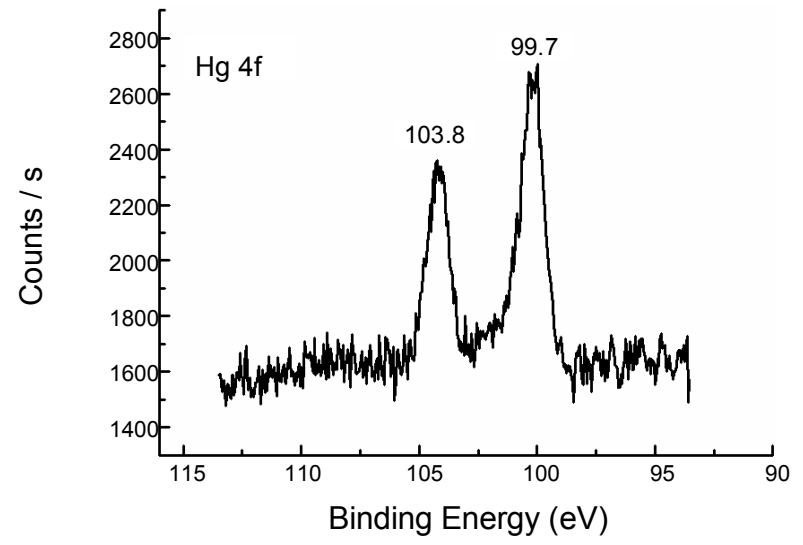

Figure 1. XPS spectra (a) survey, (b) Cd 3d, (c) Pb 4f, (d) $\mathrm{Cu} 2 \mathrm{p}$, (e) $\mathrm{Hg} 4 \mathrm{f}$ of Cd, $\mathrm{Pb}, \mathrm{Cu}$, and $\mathrm{Hg}$, deposited on the surface of a BDD electrode.

(II), and $\mathrm{Hg}$ (II) for $5 \mathrm{~min}$. The peak currents of the metal ions were strongly influenced by the $\mathrm{pH}$ of the phosphate buffer solution. From $\mathrm{pH} 5.0$ to 6.0, all of the peak currents for $\mathrm{Pb}$ (II), $\mathrm{Cu}$ (II), and $\mathrm{Hg}$ (II) increased, except for Cd (II). Above $\mathrm{pH}$ 6.0, the peak currents for $\mathrm{Pb}$ (II), $\mathrm{Cu}$ (II), $\mathrm{Hg}$ (II), and $\mathrm{Cd}$ (II) peak decreased. This can be attributed to the formation of a hydroxide precipitate at the higher $\mathrm{pH}$. Therefore, when a phosphate buffer solution is used, the optimum $\mathrm{pH}$ is 6.0. As shown in Fig. 4(b), the current responses were also strongly influenced by the $\mathrm{pH}$ of the acetate buffer solution. From pH 3.0 to 6.0, the peak currents for $\mathrm{Cd}$ (II), $\mathrm{Pb}$ (II), $\mathrm{Cu}$ (II), and $\mathrm{Hg}$ (II) gradually increased and the maximum currents were observed at $\mathrm{pH} 6.0$ in a $0.1 \mathrm{M}$ acetate buffer solution. A sharp decrease in peak current was observed as the $\mathrm{pH}$ was increased to over 6.0, due to the formation of a hydroxid ${ }^{\mathrm{e}}$ precipitate. The peak currents for metal ions in acetate buffer were higher than those in phosphate buffer. It is especially noteworthy that the peak current for $\mathrm{Cu}$ (II) in $0.1 \mathrm{M}$ acetate buffer $(\mathrm{pH}$ 6.0) was about 3 times higher than that in $0.1 \mathrm{M}$ phosphate buffer. These results indicate that the type of buffer used clearly can have an effect on the DPASV peak current. Therefore, a $0.1 \mathrm{M}$ acetate buffer $(\mathrm{pH}$ 6.0) was determined to be the optimum buffer solution.

Interference effect. The effect of a number of interfering cations on the determination of $\mathrm{Cd}$ (II), $\mathrm{Pb}$ (II), $\mathrm{Cu}$ (II), and $\mathrm{Hg}$ (II) was also investigated. This was done by using a $100 \mathrm{mV}$ pulse amplitude after placing the BDD electrode in an acetate buffer (pH 6.0) containing $100 \mathrm{ppb}$ of $\mathrm{Cd}$ (II), $\mathrm{Pb}$ (II), $\mathrm{Cu}$ (II), and $\mathrm{Hg}$ for 5 min at $-1.5 \mathrm{~V}$. The peak currents for $\mathrm{Cd}$ (II), $\mathrm{Pb}$ (II), $\mathrm{Cu}$ (II), 


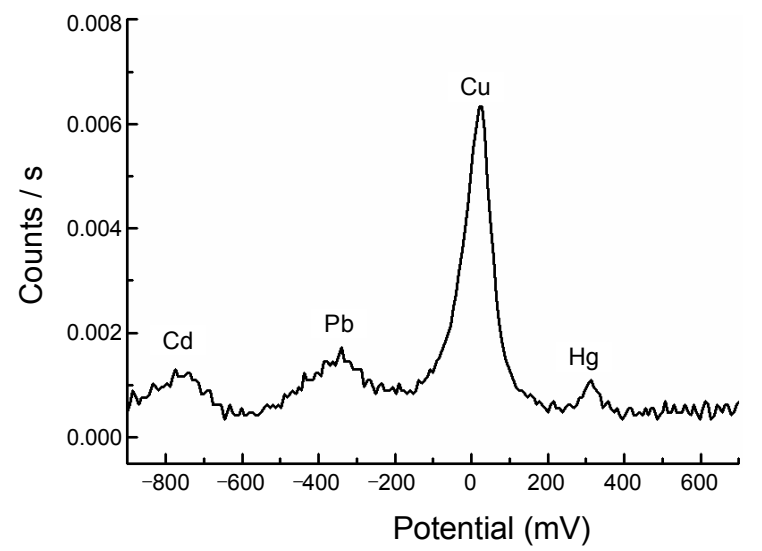

Figure 2. Responses of the BDD electrode for $100 \mathrm{ppb}$ of Cd (II), $\mathrm{Pb}$ (II), $\mathrm{Cu}$ (II), and $\mathrm{Hg}$ (II) ions in a $0.1 \mathrm{M} \mathrm{KNO}_{3}$ solution Operating conditions: $\mathrm{E}_{\mathrm{dep}}=-1.5 \mathrm{~V} ; \mathrm{t}_{\mathrm{dep}}=5 \mathrm{~min}$; stripping at $50 \mathrm{mVs}^{-1}$.
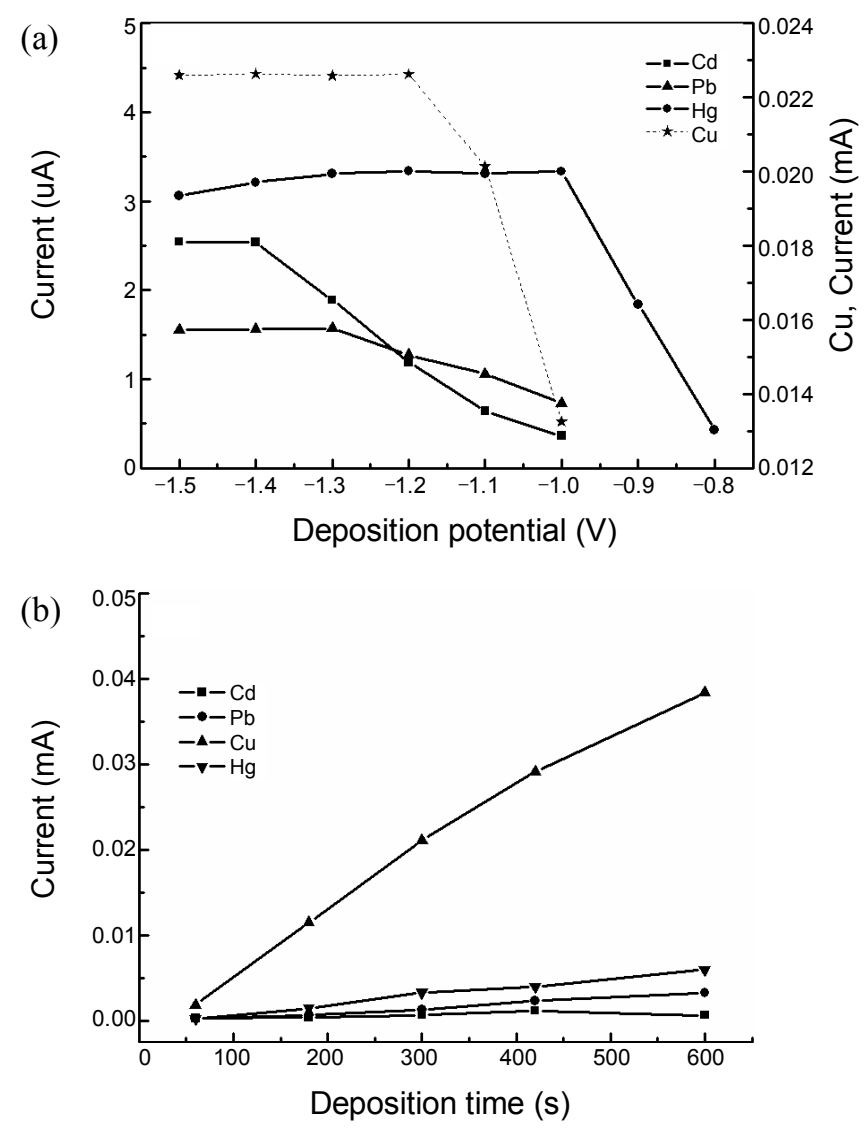

Figure 3. The current variation plots on the effect of (a) the deposition potential and (b) the deposition time in an acetate buffered solution at the BDD electrode for $100 \mathrm{ppb}$ of $\mathrm{Cd}$ (II), $\mathrm{Pb}$ (II), $\mathrm{Cu}$ (II), and $\mathrm{Hg}$ (II) ions. The scan rate is $50 \mathrm{mVs}^{-1}$.

and $\mathrm{Hg}$ (II) were reduced by about $3 \%$ in the presence of a 50 fold excess of Fe (II), Ni (II), Co (II), and Zn (II) ions. However, equimolar concentration of cations such as $100 \mathrm{ppb} F e$ (II), Ni (II), $\mathrm{Co}$ (II), and Zn (II) had no effect on the peak currents for 100 ppb Cd (II), $\mathrm{Pb}$ (II), $\mathrm{Cu}$ (II), and $\mathrm{Hg}$ (II) ions.

Calibration plot. Calibration plots for DPASV were obtained (a)

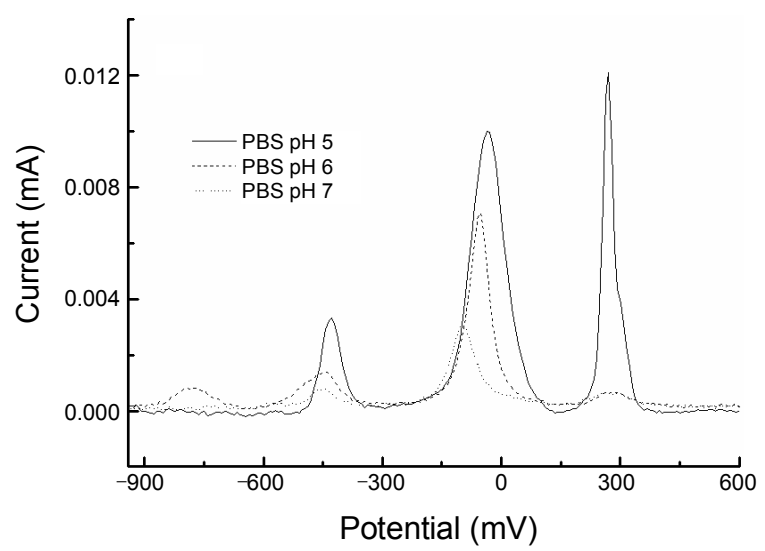

(b)

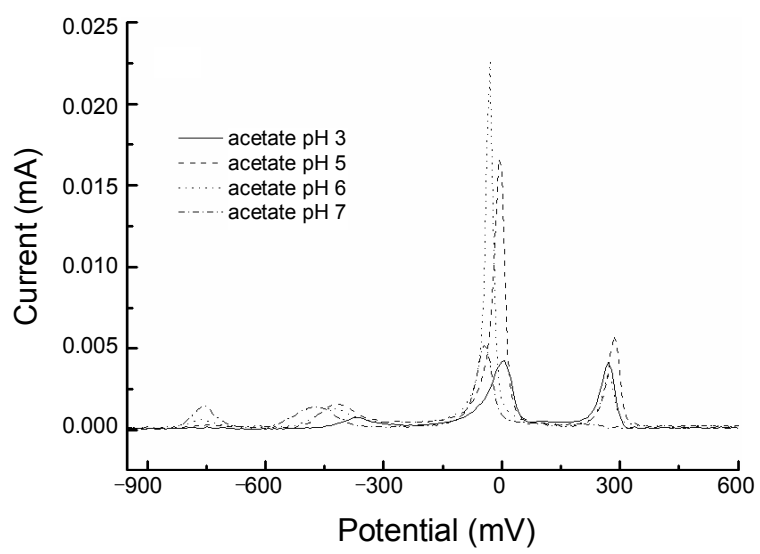

Figure 4. Effects of buffer and $\mathrm{pHs}$ of the deposition solution on the responses of $100 \mathrm{ppb}$ of $\mathrm{Cd}$ (II), $\mathrm{Pb}$ (II), $\mathrm{Cu}$ (II), and $\mathrm{Hg}$ (II) ions at BDD electrode. (a) Phosphate buffered solutions, (b) Acetate buffered solutions, Operating conditions: $\mathrm{E}_{\mathrm{dep}}=-1.5 \mathrm{~V} ; \mathrm{t}_{\mathrm{dep}}=5 \mathrm{~min}$; stripping at $50 \mathrm{mVs}^{-1}$

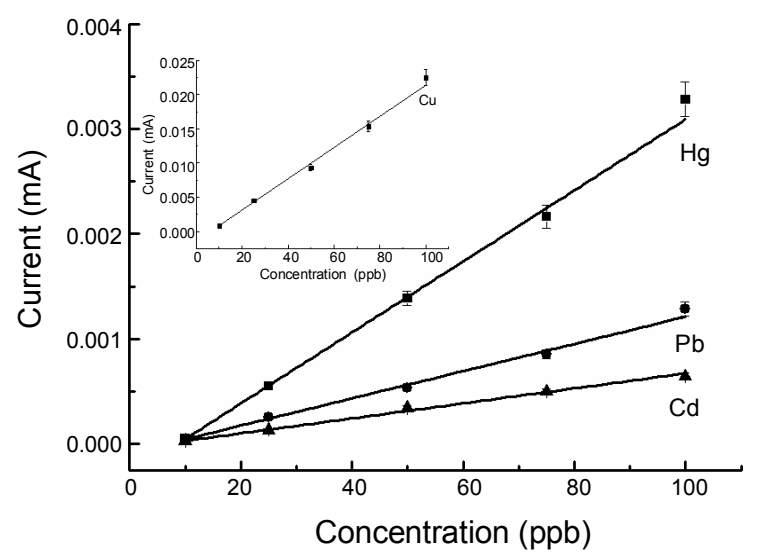

Figure 5. Calibration plots for $\mathrm{Cd}$ (II), $\mathrm{Pb}$ (II), $\mathrm{Cu}$ (II), and $\mathrm{Hg}$ (II) ions in $\mathrm{pH} 6.0$ acetate buffer: concentration range (10 ppb to $100 \mathrm{ppb})$ at the BDD electrode. Operating conditions: $\mathrm{E}_{\mathrm{dep}}=-1.5 \mathrm{~V} ; \mathrm{t}_{\mathrm{dep}}=5 \mathrm{~min}$; stripping at $50 \mathrm{mVs}^{-1}$.

using a $100 \mathrm{mV}$ pulse amplitude after placing the BDD electrode in acetate buffer ( $\mathrm{pH} 6.0)$ for $5 \mathrm{~min}$ at $-1.5 \mathrm{~V}$. The concentrations of $\mathrm{Cd}$ (II), $\mathrm{Pb}$ (II), $\mathrm{Cu}$ (II), and $\mathrm{Hg}$ (II) in the acetate buffer were varied from $10 \mathrm{ppb}$ to $100 \mathrm{ppb}$ (Fig. 5) during the experiment. The results of $\mathrm{Cd}$ (II), $\mathrm{Pb}$ (II), $\mathrm{Cu}$ (II), and $\mathrm{Hg}$ (II) using BDD with DPASV are presented in Table 1 . The detection limits were 
Table 1. Characteristics of calibration plots for $\mathrm{Cd}$ (II), $\mathrm{Pb}$ (II), $\mathrm{Cu}$ (II), and $\mathrm{Hg}$ (II) ions using BDD with DPASV. Operating conditions: Edep = $-1.5 \mathrm{~V} ; \mathrm{t}_{\mathrm{dep}}=5 \mathrm{~min}$; stripping at $50 \mathrm{mVs}^{-1}$.

\begin{tabular}{lcccc}
\hline \multicolumn{1}{c}{ parameter } & $\mathrm{Cd}(\mathrm{II})$ & $\mathrm{Pb}(\mathrm{II})$ & $\mathrm{Cu}(\mathrm{II})$ & $\mathrm{Hg}(\mathrm{II})$ \\
\hline Detection limits $(\mathrm{ppb}) \mathrm{S} / \mathrm{N} \geq 3$ & 3.5 & 2.0 & 0.1 & 0.7 \\
Linear dependences $\mathrm{i}_{\mathrm{p}}(\mu \mathrm{A})$ & $-0.04( \pm 0.0032)$ & $-0.08( \pm 0.0054)$ & $-1.56( \pm 0.0920)$ & $-0.29( \pm 0.0075)$ \\
Correlation coefficients & $+0.007( \pm 0.0002)$ & $+0.01( \pm 0.0004)$ & $+0.23( \pm 0.0075)$ & $+0.03( \pm 0.0007)$ \\
R.S.D & 0.9956 & 0.9957 & 0.9958 & 0.9982 \\
\end{tabular}

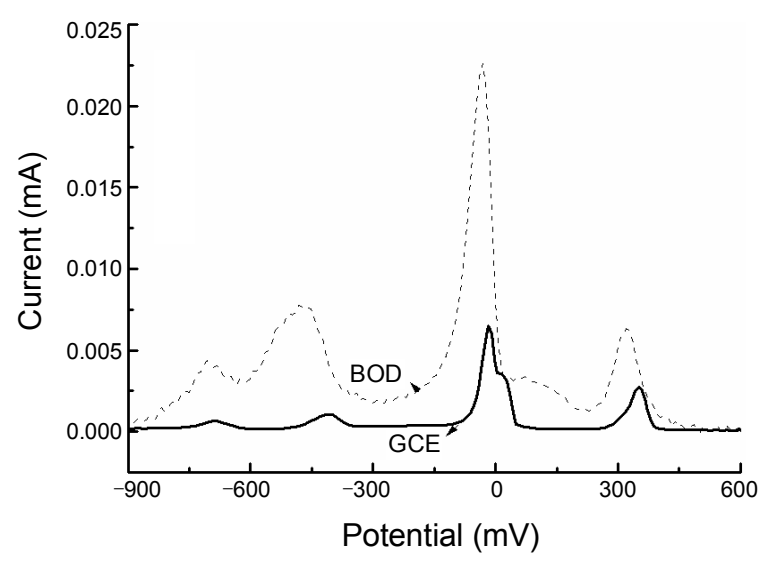

Figure 6. Differential pulse anodic stripping voltammograms obtained at BDD electrode and GCE in an acetate buffer solution containing $100 \mathrm{ppb}$ of $\mathrm{Cd}$ (II), $\mathrm{Pb}$ (II), $\mathrm{Cu}$ (II), and $\mathrm{Hg}$ (II) ions. Operating conditions: $\mathrm{E}_{\mathrm{dep}}=-1.5 \mathrm{~V} ; \mathrm{t}_{\mathrm{dep}}=5 \mathrm{~min}$; stripping at $50 \mathrm{mVs}^{-1}$.

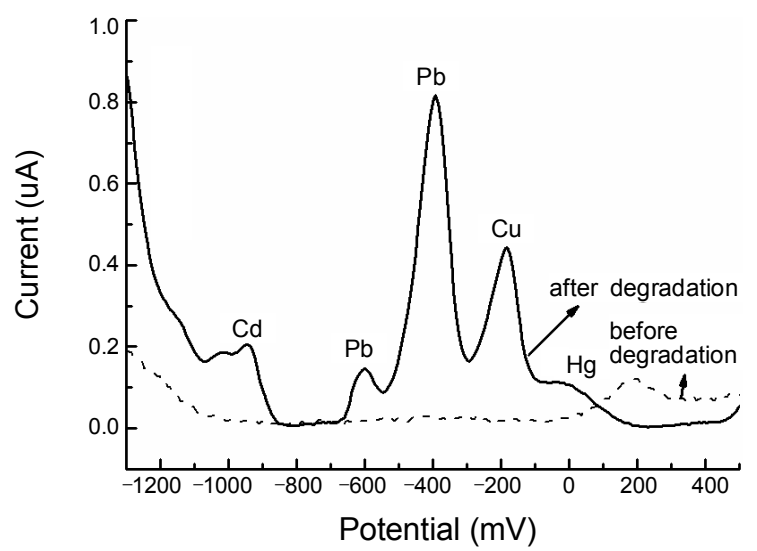

Figure 7. Responses of the BDD electrode with or without an electrochemical pre-treatment of the waste water sample.

determined based on three times the standard deviation of the blank noise ( $95 \%$ confidence level, $\mathrm{k}=3, \mathrm{n}=5)$. The detection limit values for $\mathrm{Cd}$ (II), $\mathrm{Pb}$ (II), $\mathrm{Cu}$ (II), and $\mathrm{Hg}$ (II) ions were determined to be $3.5 \mathrm{ppb}, 2.0 \mathrm{ppb}, 0.1 \mathrm{ppb}$, and $0.7 \mathrm{ppb}$, respectively. We previously studied ${ }^{22}$ the determination of copper at Pt-nanoparticle incoporated carbon paste electrode. The detection limit of copper was determined as $1.0 \mathrm{ppb}$ with the relative standard deviation of $4.2 \%$, that was about 10 times higher than the present work.

Current efficiency between a glassy carbon electrode (GCE) and BDD. It was interesting to compare the BDD electrode to a classical glassy carbon electrode (GCE), which has been recognized as an interesting electroanalytical tool because of its low sensitivity to memory effects and has been widely used for the detection of heavy metals. To accomplish this, comparable conditions were fixed for both electrodes, and, in particular, the surface of the sensor was $3 \mathrm{~mm}$ in diameter in both cases. Fig. 6 shows the four metals stripping peaks for GCE and BDD. The analysis was carried out at a deposition potential of $-1.5 \mathrm{~V}$ after 5 min deposition time in an acetate buffer solution. The peak currents for $\mathrm{Cd}$ (II), $\mathrm{Pb}$ (II), $\mathrm{Cu}$ (II), and $\mathrm{Hg}$ (II) ions at BDD electrode were 10 times higher than that for GC. The low detection limits in the present work clearly demonstrate that this method is quite suitable for use in the simultaneous analysis of Cd (II), $\mathrm{Pb}$ (II), $\mathrm{Cu}$ (II), and $\mathrm{Hg}$ (II) in actual water samples. The detection is obviously much better at BDD than at GCE. In addition, the potential range of BDD is wider than GCE.

Application. To test the applicability of the BDD electrode in an actual situation, the simultaneous determination of Cd (II), $\mathrm{Pb}$ (II), $\mathrm{Cu}$ (II), and $\mathrm{Hg}$ (II) was carried out in an as-received dye waste water sample. It is not possible to observe metal ion peaks in a waste water sample without any pretreatment. This is likely because of the multitude of organic pollutants, which can interfere the responses of metals, present in typical waste water samples. Thus, the waste water was first degraded prior to the DPASV measurements, and was then analyzed using the BDD electrode. The electrochemical degradation of $80 \mathrm{~mL}$ sample of waste water solution was accomplished at $1.1 \mathrm{~A}$ for $1 \mathrm{hr}$ using an in-house fabricated flow through electrochemical cell. The reactant solution was circulated $(10 \mathrm{~min} / \mathrm{L})$ by means of a Master Flex ${ }^{\circledR}$ L/S Micro pump (Cole-Parmer Instrument Company, USA) during the electrochemical degradation progressed. The DPASV results before degradation and after degradation were compared (Fig. 7). In addition, the positions for the each peak were confirmed by comparing the peak before and after adding a standard solution of metal ion to the waste water. DPASV clearly showed the presence of $\mathrm{Cd}$ (II), $\mathrm{Pb}$ (II), $\mathrm{Cu}$ (II), and $\mathrm{Hg}$ (II) peaks after the degradation process, and the peaks were shifted in a negative direction. This may be due to the degradation step. The concentrations of the $\mathrm{Cd}$ (II), $\mathrm{Pb}$ (II), $\mathrm{Cu}$ (II), and $\mathrm{Hg}$ (II) were determined to be 19.1, 58.9, 7.4, and $9.2 \mathrm{ppb}$, respectively by calibration curve. Thus, it can be concluded that the BDD electrode has the capability for determining the levels of $\mathrm{Cd}$ (II), $\mathrm{Pb}$ (II), $\mathrm{Cu}$ (II), and $\mathrm{Hg}$ (II) in waste water.

\section{Conclusion}

The optimized conditions for the deposition of heavy metal 
ions are as follows; (deposition buffer: acetate buffer ( $\mathrm{pH}$ 6.0), deposition time: $5 \mathrm{~min}$, deposition potential: $-1.5 \mathrm{~V}$, and pulse amplitude: $100 \mathrm{mV}$. A XPS spectrum of heavy metal ions deposited on the BDD clearly showed that the heavy metal ions were well deposited on the electrode. Thus, the BDD electrode can be used for the simultaneous determination of Cd (II), $\mathrm{Pb}$ (II), $\mathrm{Cu}$ (II), and $\mathrm{Hg}$ (II) ions using DPASV. The dynamic ranges of the BDD electrode were found to be from $10 \mathrm{ppb}$ to $100 \mathrm{ppb}$ and the detection limits of $\mathrm{Cd}$ (II), $\mathrm{Pb}$ (II), $\mathrm{Cu}$ (II), and $\mathrm{Hg}$ (II) ions were determined to be $3.5 \mathrm{ppb}, 2.0 \mathrm{ppb}, 0.1 \mathrm{ppb}, 0.7 \mathrm{ppb}$, respectively. Interference by other metal ions in the determination of $\mathrm{Cd}$ (II), $\mathrm{Pb}$ (II), $\mathrm{Cu}$ (II), and $\mathrm{Hg}$ (II) ions with the BDD electrode was negligible and the response of the BDD electrode was higher than that for a GC electrode. The BDD electrode could be used for the simultaneous determination of $\mathrm{Cd}$ (II), $\mathrm{Pb}$ (II), $\mathrm{Cu}$ (II), and $\mathrm{Hg}$ (II) in waste water samples.

Acknowledgments. This work was supported by grants of KBSI T29605, and NCRC program of KOSEF R15-200602201002-0.

\section{References}

1. Goyer, R. A. Toxicology, The Basic Science of Poisons; fifth ed.; Klaassen, C. D., Ed.; McGraw-Hill: New York, 1996; p 691.

2. Lead in Drinking Water, http://www.epa.gov/safewater/lead/ leadfacts. html, July 2005.
3. Hwang, T. J.; Jiang, S. J. J. Anal. At. Spectrosc. 1996, 11, 353.

4. Liu, H. W.; Jiang, S. J.; Liu, S. H. Spectrochim. Acta Part B 1999, $54,1367$.

5. Das-Ak Chakraborty, R.; Cervera, M. L.; Delaguardia, M. Mikrochim. Acta 1996, 122, 209.

6. When, J.; Cassidy, R. M. Anal. Chem. 1996, 68, 1047.

7. McGaw, E. A.; Swain, G. M. Anal. Chim. Acta 2006, 575, 180.

8. Wang, S. P.; Forzani, E. S.; Tao, N. J. Anal. Chem. 2007, 79, 4427.

9. Florence, T. M. J. Electroanal. Chem. Interfac. Electrochem. 1970, 27, 273.

10. Dong, S.; Wang, Y. Talanta 1988, 35, 819.

11. Rahman, Md. A.; Won, M. S.; Shim, Y. B. Anal. Chem. 2003, 75, 1123.

12. Nolan, M. A. Anal. Chem. 1999, 71, 3567.

13. Jena, B. K.; Retna, R. C. Anal. Chem. 2008, 80, 4836.

14. Bonfil, Y.; Kirowa-Eisner, E. Anal. Chim. Acta 2002, 457, 285.

15. Wang, J.; Lu, J.; Hocevar, S. B.; Farias, P. A. M.; Ogoreve, B. Anal. Chem. 2000, 72, 3218.

16. Pauliukaite, R.; Hocevar, S. B.; Ogorevc, B.; Wang, J. Electroanalysis 2004, 16, 719.

17. Manivannan, A.; Tryk, D. A.; Fujishima, A. Electrochem. Solid State Lett. 1999, $2,455$.

18. Prado, C.; Wilkins, S. J.; Marken, F.; Compton, R. G. Electroanalysis 2002, 14, 262.

19. Manivannan, A.; Kawasaki, R.; Tryk, D. A.; Fujishima, A. Electrochimica 2004, 49, 3313.

20. Tall, O. E.; Jaffrezic-Renault, N.; Sigaud, M.; Vittori, O. Electroanalysis 2007, 19, 1152.

21. www.lasurface.com/database

22. Yoon, J. H.; Muthuraman, G.; Yang, J. E.; Shim, Y. B.; Won, M. S. Electroanalysis 2007, 19, 1160. 